\title{
Acute ischemic stroke mimicking subarachnoid hemorrhage after coronary angioplasty
}

\author{
ANA PIRŠIĆ ${ }^{1}$, TOMISLAV ŠIPIĆ ${ }^{2}$ KREŠIMIR ŠTAMBUK ${ }^{2}$, HRVOJE BUDINČEVIĆ ${ }^{1,3}$ \\ ${ }^{1}$ Sveti Duh University Hospital, Department of Neurology, Stroke and Intensive Care Unit, Sveti Duh 64, 10000 Zagreb, Croatia \\ ${ }^{2}$ Magdalena Clinic for Cardiovascular Surgery and Cardiology, Department of Cardiology, \\ Ljudevita Gaja 2, 49217 Krapinske Toplice, Croatia \\ ${ }^{3}$ School of Medicine, Josip Juraj Strossmayer University of Osijek, Osijek, Croatia
}

\begin{abstract}
Use of non-ionic contrast media (CM) in coronary arteriography has been reported to cause transient cortical blindness, confusion, amnesia and very rare focal deficits. We report a 69 -year old patient with stable angina pectoris who underwent coronary angioplasty with stent placement due to in-stent thrombosis of the right coronary artery and developed stroke symptoms with radiological suspicion of subarachnoid hemorrhage. No vascular malformations were detected on CT cerebral angiography. Dual antiplatelet treatment was continued. Complete neurological recovery was observed within 48 hours post angiography. As observed with repeated CT scans, sulcal hyperdensities mostly faded after 24 hours and totally disappeared within 7 days when she was discharged home. Our case shows transient neurological symptoms and rapid disappearing of sulcal hyperdensities, suggesting temporary blood brain barrier disruption, consequential cerebral infarction and contrast media extravasation as the main mechanisms which allowed us to treat the patient with dual antiplatelet treatment.
\end{abstract}

Key words: neurotoxicity syndromes, contrast media, blood-brain barrier, cerebral infarction, subarachnoid hemorrhage.

\section{INTRODUCTION}

Use of non-ionic contrast media $(\mathrm{CM})$ in coronary arteriography has been reported to cause transient cortical blindness, confusion, amnesia and very rare focal deficits $[1,2]$. The proposed mechanisms of neurotoxicity are disruption of the blood-brain barrier (BBB) and a direct neurotoxic effect by CM [3]. Abnormal contrast enhancement on brain computed tomography (CT) scan after diagnostic or interventional angiography is not rare and has known to be induced by temporary BBB disruption from CM [3]. The aim of this case report is to show mimicking subarachnoid hemorrhage (SAH) caused by contrast extravasation due to dysfunction of BBB in acute ischemic stroke.

\section{CASE REPORT}

A 69-year old woman, with stable angina pectoris, arterial hypertension, diabetes and stent placement in right coronary artery (RCA) eight years earlier, underwent transfemoral coronary angioplasty with recanalization and stent placement in RCA due to subtotal in-stent restenosis. Additional treatment included $10000 \mathrm{IU}$ heparin, aspirin $100 \mathrm{mg}$ and clopidogrel $600 \mathrm{mg}$. A half an hour after the procedure, she suffered chest pain with aphasia, confusion and right hand paresis. She underwent second interventional procedure with recanalization and two stents placement due to confirmed acute in-stent thrombosis, followed by eptifibatid bolus and infusion. A non-ionic contrast iohexol was used in both procedures, in an amount of 350 milliliters both times. Immediately after, she underwent neurological examination which revealed recovery of aphasia and persistence of right central facial palsy, right mild hemiparesis and hemihypoesthesia with facilitated tendon reflexes. Brain CT showed acute cortical and subcortical frontoparietal cerebral infarction with hyperdense $(50-75 \mathrm{HU})$ content filling the sulci of left hemisphere, which was diagnosed as SAH (Fig. 1a). At this time the patient was referred to our Stroke and Intensive Care Unit. No vascular malformations were detected on CT cerebral angiography. To consider other causes of $\mathrm{SAH}$, it is valuable to notice that prior to this event, she was not treated with anticoagulation therapy or steroids and she did not have any clinical signs which would corroborate the diagnosis of vasculitis or reversible cerebral vasoconstriction syndrome. There were no signs of vasospasm during transcranial doppler ultrasonography. Dual 
antiplatelet treatment including aspirin and clopidogrel was continued. Complete neurological recovery was observed within 48 hours after angiography. As observed with repeated CT scans, cerebral infarction was sequentially detected opposite to sulcal hyperdensities that mostly faded after 24 hours (Fig. 1b) and totally disappeared within 7 days when she was discharged home (Fig. 1c).

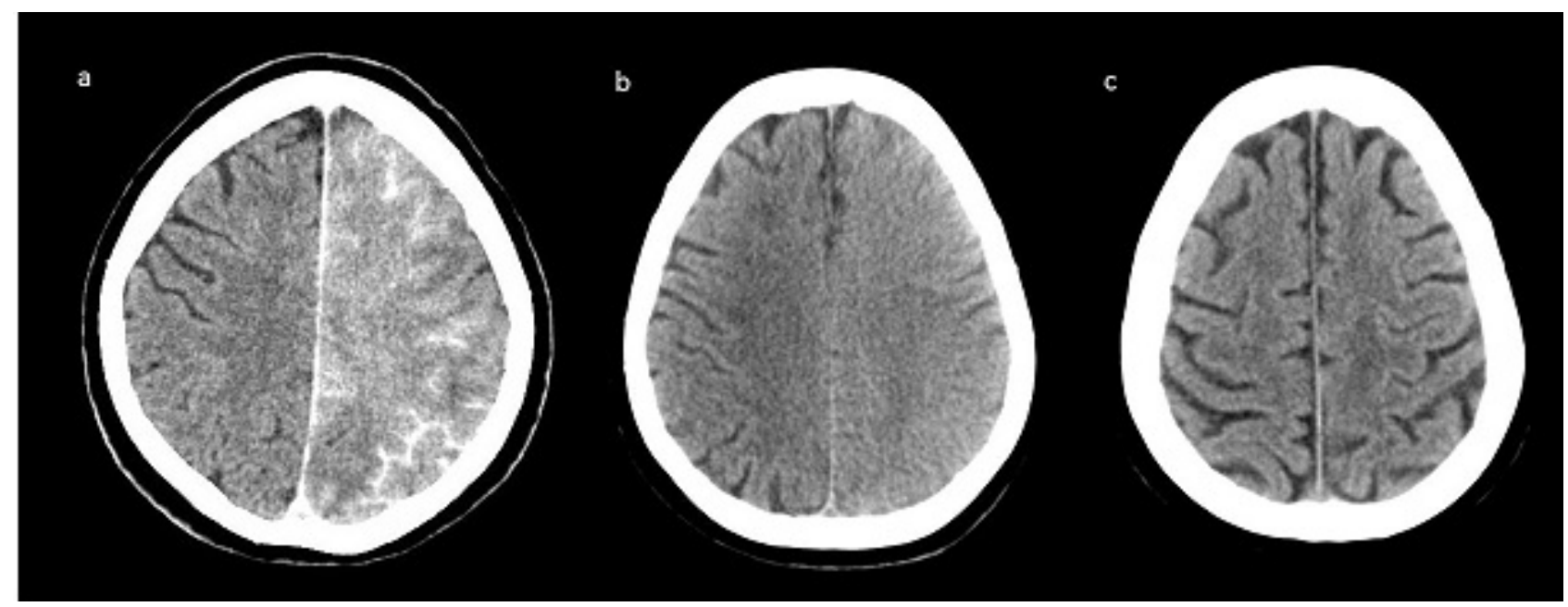

Figure 1. Series of brain CT scans in patient with blood-brain barrier disruption, cortical and subcortical frontoparietal cerebral infarction and hyperdense content filling the sulci of left hemisphere mimicking subarachnoid hemorrhage at $3 \mathrm{~h}(\mathrm{a})$, fading in $24 \mathrm{~h}(\mathrm{~b})$ and totally disappeared in 7 days (c).

\section{DISCUSSION}

In-hospital cerebrovascular accident after per-cutaneous coronary intervention (PCI) occurs in about $0.30 \%$ of procedure [4]. Our case shows transient neurological symptoms and rapid disappearing of sulcal hyperdensities, suggesting temporary BBB disruption, consequential cerebral infarction and $\mathrm{CM}$ extravasation as the main mechanisms that allowed us to treat the patient with dual antiplatelet therapy. The usage of dual antiplatelet therapy was necessary in treatment of coronary disease and ischemic stroke prevention. The coexistence of SAH remains unlikely. Although the specificity of $\mathrm{CT}$ for SAH is very high, physicians should be aware of rare false positive findings [5]. CM extravasation could mimic radiologically $\mathrm{SAH}$ which is likely to occur in cases in which more than one revascularization is performed [6]. The density of the lesion measured in Hounsfields units (HU) could be a useful distinguishing characteristic, which is confirmed in a recently published review of 53 published cases of "contrast induced encephalopathy" noting that blood density is ranging between 40 and $60 \mathrm{HU}$ and contrast media usually between 100 and $300 \mathrm{HU}$ [7]. Magnetic resonance imaging (MRI)-derived apparent diffusion coefficient (ADC) was shown as a reliable imaging modality that differentiates contrast extravasation from cerebral ischemia [8]. Other authors have suggested dual energy scanning (DECT) in distinguishing intracranial hemorrhage from iodinated contrast extravasation or staining [9]. In the absence of those techniques, in stable patient with resolving symptoms, standard of care could be repeated follow-up imaging [10], usually showing that contrast staining generally washes out within 24-48 hours, while hemorrhage persists for days to weeks [9]. In our case, brain MR was not performed because recent stent placement (hospital protocol does not allow MRI within 3 months after stent placement) [11] and clinical improvement with contrast clearance on serial brain CTs. The spinal puncture was not performed based on our opinion that there would be a high risk for spinal bleeding without a real benefit to the patient. Physicians who treat the patients with cerebrovascular complications after PCI, and who do not have possibility of the proposed novel MRI and $\mathrm{CT}$ techniques, could find our case report helpful in making their clinical decisions. A careful follow-up, especially in a stable patient with resolving neurological deficit, would be reasonable in order to postpone or completely avoid potentially harmful additional $\mathrm{CM}$ administration and/or spinal puncture with high risk of bleeding, in this group of patients recently treated with multiple antithrombotic drugs.

\section{Acknowledgements. None.}

Conflict of Interest disclosure. The authors declare that there are not conflicts of interest. 
Folosirea substanțelor de contrast neionice pentru angiografie s-a asociat cu cecitate tranzitorie, confuzie, amnezie şi foarte rar cu deficite de focar. Prezentăm cazul unui pacient de 69 de ani cu angina stabilă care a suferit o angioplastie coronariană cu amplasarea unui nou stent datorită dezvoltării unei tromboze la nivelul stentului anterior şi care ulterior a dezvoltat semnele unui atac vascular cerebral cu suspiciune radiologică de hemoragie subarahnoidiană. Nu au fost detectate malformații ale arterelor cerebrale după realizarea angio-CT-ului. Terapia dublă antiagregantă s-a continuat la acest pacient. Refacerea completă neurologică s-a realizat la 48 de ore după realizarea angiografiei.Pacientului i-au fost realizate analize CT înseriate şi s-au observant hiperdensități la nivelul sulcului care s-au estompat la 24 de ore după atac şi care au dispărut complet la 7 zile, moment în care pacientul a fost externat. Cazul nostru prezintă simptome tranzitorii neurologice şi o rapidă dispariție a hiperdensităților sulcale, sugerând o pierdere temporară a barierei hematoencefalice, cu dezvoltarea de infarct cerebral şi extravazarea substanței de contrast, permițând abordarea pacientului cu terapie dublă antiagregantă.

Correspondence to: HRVOJE BUDINČEVIĆ, MD, PhD,

Sveti Duh University Hospital. Department of Neurology,

Stroke and Intensive Care Unit. Sveti Duh 64, 10000 Zagreb, Croatia

E-mail: hbudincevic@gmail.com

\section{REFERENCES}

1. STICHERLING C, BERKEFELD J, AUCH-SCHWELK W, LANFERMANN H. Transient bilateral cortical blindness after coronary angiography. Lancet 1998; 351:570.

2. VELDEN J, MILZ P, WINKLER F, SEELOS K, HAMANN GF. Nonionic contrast neurotoxicity after coronary angiography mimicking subarachnoid hemorrhage. Eur Neurol 2003; 49:249-251.

3. LEE KK, KANG DH, KIM YS, PARK J. Serious Blood-Brain Barrier Disruption after Coil Embolization of Unruptured Intracranial Aneurysm : Report of Two Cases and Role of Immediate Postembolization CT Scan. J Korean Neurosurg Soc 2011; 50:45-47.

4. ZHANG F, FENG LQ, BI Q, WANG YP. Characteristics and risk factors of cerebrovascular accidents after percutaneous coronary interventions in patients with history of stroke. Chin Med J (Engl). 2010; 123:1515-1519.

5 SHARP S, STONE J, BEACH R. Contrast agent neurotoxicity presenting as subarachnoid hemorrhage. Neurology 1999; 52:1503-1505.

6. OH MS, KWON JE, KIM KJ et al. Subarachnoid hemorrhage mimicking leakage of contrast media after coronary angiography. Korean Circ J 2012; 42:197-200.

7. SPINA R, SIMON N, MARKUS R, MULLER DW, KATHIR K. Contrast-induced encephalopathy following cardiac catheterization. Catheter Cardiovasc Interv 2016 [Epub ahead of prin].

8. LIAO MT, LIN TT, LIN LY, HWANG JJ, TSENG CD. Contrast-induced encephalopathy after percutaneous coronary intervention. Acta Cardiol Sin. 2013; 29:277-280.

9. PHAN CM, YOO AJ, HIRSCH JA, NOGUEIRA RG, GUPTA R. Differentiation of hemorrhage from iodinated contrast in different intracranial compartments using dual-energy head CT. AJNR Am J Neuroradiol 2012; 33:1088-1094.

10. MERICLE RA, LOPES DK, FRONCKOWIAK MD, WAKHLOO AK, GUTERMAN LR, HOPKINS LN. A grading scale to predict outcomes after intra-arterial thrombolysis for stroke complicated by contrast extravasation. Neurosurgery 2000; 46:1307-1314.

11. LEVINE GN, GOMES AS, ARAI AE et al. Safety of magnetic resonance imaging in patients with cardiovascular devices: an American Heart Association scientific statement from the Committee on Diagnostic and Interventional Cardiac Catheterization, Council on Clinical Cardiology, and the Council on Cardiovascular Radiology and Intervention: endorsed by the American College of Cardiology Foundation, the North American Society for Cardiac Imaging, and the Society for Cardiovascular Magnetic Resonance. Circulation 2007; 116:2878-2891.

Received December 21, 2016 